\title{
Perceived Economic Value of Ecosystem Services in the US Rio Grande Basin
}

\author{
Weiwei Wang ${ }^{1, *}$, Jianhong E. Mu ${ }^{2}$ and Jadwiga R. Ziolkowska ${ }^{3}$ \\ 1 School of Business, Nanjing University of Information Science and Technology, Nanjing 210044, China \\ 2 Environment and Planning Program, Texas A\&M Transportation Institute, Texas A\&M University System, \\ Austin, TX 78752, USA; j-mu@tti.tamu.edu \\ 3 Department of Geography and Environmental Sustainability, University of Oklahoma, Norman, OK 73019, \\ USA; jziolkowska@ou.edu \\ * Correspondence: weiwei.wang23@outlook.com
}

Citation: Wang, W.; Mu, J.E.

Ziolkowska, J.R. Perceived Economic Value of Ecosystem Services in the US Rio Grande Basin. Sustainability 2021, 13, 13798. https://doi.org/10.3390/ su132413798

Academic Editor: Alessandra De Marco

Received: 25 September 2021

Accepted: 4 December 2021

Published: 14 December 2021

Publisher's Note: MDPI stays neutral with regard to jurisdictional claims in published maps and institutional affiliations.

Copyright: (c) 2021 by the authors. Licensee MDPI, Basel, Switzerland. This article is an open access article distributed under the terms and conditions of the Creative Commons Attribution (CC BY) license (https:/ / creativecommons.org/licenses/by/ $4.0 /)$.

\begin{abstract}
In recent decades, the US Rio Grande Basin has experienced serious ecosystem degradation as a result of recurring severe droughts and a growing population. Monetary valuation of ecosystem services is essential for encouraging conservation where natural resources such as freshwater are limited. Research in this field is still very limited, and economic estimations of ecosystem services in the US Rio Grande Basin have not been undertaken extensively. This study adds to the existing contemporary literature by means of the willingness-to-pay evaluation. We found the mean household wiliness to pay of total ecosystem services across the Rio Grande Basin to amount to USD 62/year, and the average perceived economic value was estimated to be USD 26.2, USD 19.7, USD 8.1, and USD 7.1 yearly for conservation of habitat for wildlife, provision of freshwater supplies, recreational activities, and cultural heritage, respectively. The income and perceptions about the importance of various ecosystem services in the Rio Grande Basin were among the main determinants of respondents' assessments. The findings provide an appropriate foundation for incorporating perceived economic value into watershed management and conservation.
\end{abstract}

Keywords: willingness-to-pay; contingent valuation; ecosystem services; economic evaluation; Rio Grande

\section{Introduction}

According to the Millennium Ecosystem Assessment [1], ecosystem services are defined as the benefits to human well-being obtained from ecosystems (biotic and abiotic elements of the environment) that serve both local communities and natural environments. Healthy freshwater ecosystems provide benefits and services that are the foundation for human and social development. Quantifying the value associated with watershed ecosystem services is useful to support environmental policy decisions and to promote sustainable watershed management and conservation [2-6].

Several economic valuation methods have been developed to assess the value of changes in ecosystem services. Non-market valuation methods are useful in cases when direct markets for ecosystem goods and services do not exist and direct market prices are missing. More specifically, the contingent valuation method (CVM) has been widely used to measure people's willingness-to-pay (WTP) for nonmarket goods or services [2,7-10]. CVM involves the use of sample surveys (questionnaires) to elicit respondents' statement of their WTP for particular changes in the provision of ecosystem services. This approach is known to have some common biases arising from strategic behavior, the survey design, the payment instrument, and the bid-amount starting point [11]. Nevertheless, it is argued that CVM should be a suitable and useful tool in detecting and communicating changes in ecosystem-services provision, thus increasing the visibility of nature in valuation [5,12-14]. Another issue with CVM is that many interviewees provide protest responses, which may 
result in a sample-selection problem in the estimation of WTP [15]. In order to correct the protest-response issue, some studies chose to remove the protest responses [16,17]. However, this is only correct if protest responses are randomly distributed across the protest-non-protest divide [18]. Overlooking the effect of protest responses would cause an upward bias of the final WTP estimation, whereas treating all protest votes as truezero bidders and including them in model estimation would cause a downward bias in WTP [19]. To test and solve for the potential sample-selection bias, the Heckman sample selection two-step model is proposed [20]. This approach has been adopted in a number of studies to correct the possible estimation bias of WTP [2,21-23].

The Rio Grande Basin's water resources and ecosystems are seriously threatened by drought and a fast-growing population [24]. Stakeholders in the Rio Grande Basin are strongly interested in solutions to address the widening gap between the declining water supplies and increasing water demands from different economic sectors and users. Although several water-management and conservation schemes have been implemented in the Rio Grande Basin (e.g., more-efficient water delivery systems, water right conversion from agriculture to urban uses, and desalination investments), none of these solutions provide a single answer to the complex water issues in the basin.

This study focused on the economic evaluation that could help incentivize residents of the Rio Grande Basin to conserve water resources and maintain ecosystem services for different applications. To address this issue, the willingness-to-pay (WTP) method was applied and Heckman's two-stage model was used for the WTP analysis. The main purpose of this research was to determine a monetary value of ecosystem services provided by the Rio Grande. Moreover, this explorative and empirical study provides insights about human perceptions regarding the importance of the river basin and related ecosystem services in all three US Rio Grande states: Colorado, New Mexico, and Texas. While research is available about some specific ecosystem services of the Rio Grande basin, or of different river sections [25-27], to our best knowledge, there is no study of perceived economic value for the US basin so far. This study offers a valuable economic assessment of ecosystem services by means of one holistic methodological approach across the entire US Rio Grande Basin. The results of this research can help guide decisions regarding water-resource conservation and management, subsequently enhancing the resilience of the river watershed to climate changes and extreme weather events [28-31].

\section{Study Area}

The Rio Grande Basin is located in the southwestern United States and spans over $870,000 \mathrm{~km}^{2}$ across three US states (Colorado, New Mexico, and Texas) and Mexico [32]. This study was conducted in the river basin within the US only (Figure 1). The study area represents a vibrant and growing region with multiple socio-economic and environmental issues related to sustainable and efficient water use and management. For example, the population in Colorado, New Mexico, and Texas almost doubled from 19.7 million to 33.3 million during 1982-2012, which raised demands for natural resources, especially freshwater. Moreover, this region experienced significant economic growth. According to the US Bureau of Economic Analysis, from 1997 to 2012, the per capita real gross domestic product (GDP) in these three states increased by 14.4, 10.2, and 22.3\%, respectively. As a result of the economic development and population growth occurring simultaneously, withdrawals of groundwater and surface water across the Rio Grande Basin increased from 19 billion gallons per day (BGD) in 1985 to 39 BGD in 2010 [33]. With reduced streamflow and recharge rates, water availability and supply for different uses in the Rio Grande Basin commenced to pose an urgent issue affecting not only human well-being but also the provision of ecosystem services. 


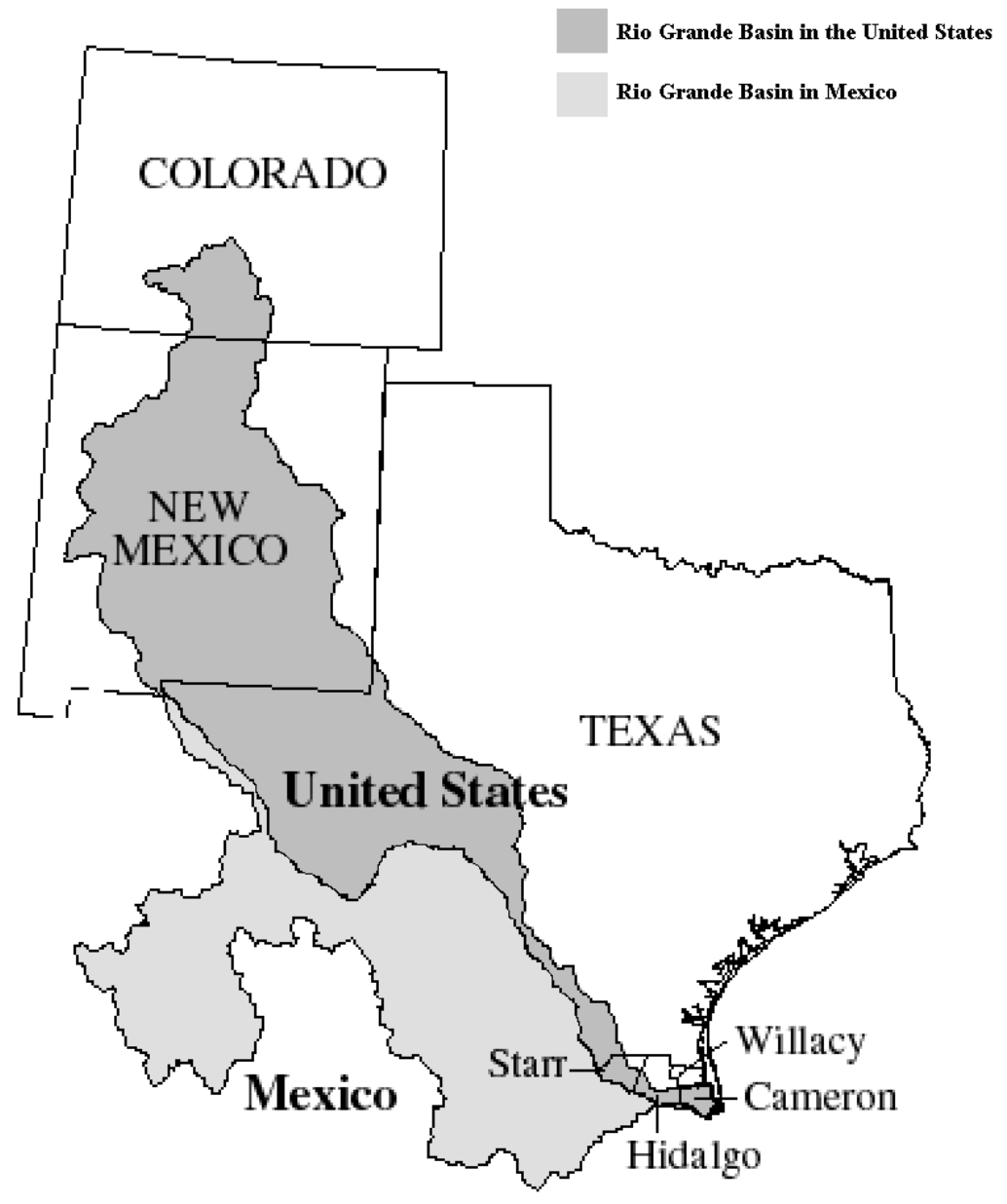

Figure 1. Location of the Rio Grande Basin. Dark gray shading shows the study area that is located within the US.

\section{Methods}

In our hypothesis, we expect personal preferences and social-economic characteristics to affect the people's WTP for conserving the ecosystem services of the Rio Grande Basin. In order to test the hypothesis, contingent valuation surveys were conducted in the first step followed by a Heckman sample-selection model to determine the economic value of water ecosystem services stemming from the US Rio Grande, unveiling the relationship between WTP and personal characteristics.

\subsection{Survey Design}

An online survey was designed with the Qualtrics software at the University of Oklahoma and approved by the University of Oklahoma-Norman Campus Institutional Review Board. During February and March 2017, the survey was validated with a pre-test run among the United States Geological Survey (USGS) project participants, collaborators, and other university scholars and students working on water-related issues. The final questionnaires were distributed by email to 350 stakeholders in the Rio Grande Basin from the beginning of May to the end of September in 2017. The participants were randomly drawn from USGS database of the residents and project collaborators in the respective basin locations.

The survey respondents include stakeholders working in different functions in the Rio Grande Basin, residents of the basin, and tourists visiting the river basin. These three distinct groups were selected through the process of random sampling and a snow-balling method, with the aim to address the potential variability of responses. 
The web-based survey contained 32 questions in three parts:

Part 1: Inquiring about respondents' perceptions regarding the status and issues of ecosystem service provision in the Rio Grande Basin;

Part 2: Inquiring about respondents' willingness-to-pay and the US dollar (\$) value they would be willing to spend on maintaining the analyzed ecosystem services in the Rio Grande Basin (a standard WTP question format was used due to its proven robustness in the literature);

Part 3: Inquiring respondents about their environmental behaviors (i.e., if the respondent was a member of either an environmental or social association) and socio-demographic characteristics (i.e., place of residence, education, age, income, etc.).

Four key ecosystem services (freshwater supplies, cultural heritage, habitat for wildlife, and recreational activities) were selected in this study based on the following criteria: representation of the different service categories of provisioning, supporting, regulating and cultural services, and the inclusion of water-related services. The freshwater supplies service directly refers to the natural river capacity (river flows) needed to sustain water provisions from the Rio Grande to communities relying on the river water for a multitude of uses. The service of habitat for wildlife (i.e., products and services derived from hunting, fishing, and plant collecting) is referred to as direct supporting and regulating services in the river basin. Cultural heritage and recreational activities (i.e., tourism activities like fishing and rafting) describe classic examples of cultural ecosystem services.

In Part 1, respondents were asked to choose from four ecosystem services most important to them and to rank them using a five-point Likert scale from one (least important) to five (most important). An ordinal measure of the social importance of each service was created from this part.

In the second part of the survey, respondents were then asked if they would be willing to pay through an annual donation to protect the Rio Grande Basin to continue providing benefits to the society. An open-ended contingent valuation format was used for eliciting respondent's WTP for maintaining ecosystem services. If the response was affirmative with an indicated maximum WTP, the authors then ascertained that the respondent would be willing to pay. If the response was negative, the follow-up question, why the respondents would not want to make a monetary contribution, was asked to distinguish protest responses from the real zero values.

\subsection{Model Specification}

Based on the survey outcomes, the Heckman two-step model was applied to the WTP analysis. The advantage of the Heckman approach is that it controls for the sample selection issue by the simultaneous estimation of two processes: selection and outcome. The first step entails the estimation of the respondent's decision to pay or not to pay through a probit regression, and the second step models the WTP for non-protesters through ordinary least squares (OLS).

Technically, the linear probit model determines the respondents' decision $(Z)$ on whether to support the preservation of ecosystem services by:

$$
Z_{i}=\left\{\begin{array}{ll}
1 & \text { if } Z_{i}^{*}>0 \\
0 & \text { if } Z_{i}^{*} \leq 0
\end{array} \text { and } Z_{i}^{*}=\alpha^{\prime} W_{i}+u_{i}\right.
$$

where: $Z_{i}^{*}$ is a latent participation variable that takes the value of 1 if the respondent would like to support the provision of ecosystem services, or 0 otherwise; $W$ is a vector of household characteristics; and $\alpha$ is a vector of parameters to be estimated with the model.

Based on the respondents' general decision about preservation of ecosystem services (Equation (1)), the stated amount of willingness-to-pay (in \$ value) was estimated using an OLS regression model:

$$
y_{i}=\left\{\begin{array}{ll}
y_{i}^{*} & \text { if } y_{i}^{*}>0 \text { and } Z_{i}^{*}>0 \\
0 & \text { otherwise }
\end{array} \text { and } y_{i}^{*}=\beta^{\prime} X_{i}+v_{i}\right.
$$


where: $y_{i}$ is the observed answer to the WTP valuation question about the $\$$ value the respondent is willing to pay for preserving ecosystem services; $X$ is a vector of individual characteristics; and $\beta$ is a vector of parameters to be estimated with this model.

In both equations, the variables represented by the $W$ and $X$ parameters can be the same or different, thus representing the same or different characteristics of the respondents depending on the variable selection. The Least Absolute Shrinkage and Selection Operator (LASSO) method was applied in the first place for the two-step model to select the mostrelevant variables conditional on a small sample size. LASSO is a regression analysis method that performs both the variable selection and regularization in order to enhance the prediction accuracy and interpretability of the statistical model it produces [34,35]. Using the LASSO method, a robust subset of covariates rather than all variables was selected to be used in the final two-step model [36]. As a result of this methodological proceeding, each equation can be characterized by a different set of variables, which provides a broader range of outcomes describing the variability of ecosystem services and their randomness in a more accurate and comprehensive way.

\section{Results}

\subsection{Descriptive Statistics}

Among the 350 surveys sent, 106 surveys had been returned with valid information; thus, the response rate was about $30.3 \%$. Of the respondents, $67 \%$ were residents of the basin, $21.7 \%$ were stakeholders working in the basin, and $11.3 \%$ were tourists visiting the basin. The socio-economic characteristics of the respondents in the survey sample were compared to the 2010 US Census data of the three states. Most characteristics in the survey had matching or closely similar values to the census data (Table 1). In the survey sample, $64.2 \%$ were male, $62.9 \%$ were white, and $100 \%$ held a college or higher degree. The median annual household income ranged between USD 60,000 and USD 80,000, and the average household size was 2.7 persons. As respondents were mostly homeowners or professionals in this region, our sample might over-represent the relatively aged and educated individuals, which should be kept in mind when applying these results to the extent of the entire Rio Grande Basin or associated states. A reliability test was conducted to confirm the reliability of the respondent's attitude variables in terms of Cronbach's alpha value. The Cronbach's alpha score for the subconstructs ranged from 0.604 to 0.842 , indicating that the survey is more reliable.

Table 1. Comparison of 2010 US Census data and survey sample data regarding socio-economic characteristics.

\begin{tabular}{|c|c|c|c|c|}
\hline \multirow{2}{*}{ Variable } & \multicolumn{3}{|c|}{ US Census } & \multirow{2}{*}{$\begin{array}{c}\text { Survey } \\
\text { Mean }\end{array}$} \\
\hline & Colorado & New Mexico & Texas & \\
\hline Median age (years) & 36.8 & 37.7 & 34.7 & 49.3 \\
\hline Female $(\%)$ & 49.5 & 50.5 & 50.4 & 35.8 \\
\hline \multicolumn{5}{|l|}{ Race/ethnicity (\%) } \\
\hline White & 68.2 & 37.4 & 41.9 & 62.9 \\
\hline Hispanic & 21.5 & 48.8 & 39.4 & 28.9 \\
\hline Black or African American & 3.9 & 1.8 & 11.8 & 1.0 \\
\hline Asian & 3.1 & 1.3 & 4.8 & 0 \\
\hline American Indian or Alaska Native & 0.6 & 8.8 & 0.3 & 2.1 \\
\hline Others & 2.7 & 1.9 & 1.8 & 5.1 \\
\hline \multicolumn{5}{|l|}{ Education attainment $*(\%)$} \\
\hline High school graduate or lower & 29.7 & 40.5 & 41.4 & 0 \\
\hline College or higher & 70.3 & 59.5 & 58.6 & 100 \\
\hline Median household income (\$) & 60,629 & 44,964 & 53,207 & $60,000-80,000$ \\
\hline Persons per household (person) & 2.6 & 2.7 & 2.8 & 2.7 \\
\hline
\end{tabular}

Table 2 provides definition and summary statistics for the variables used in the model. Overall, $75.5 \%$ of the sample responded "yes" to the CVM question with a stated value. The remaining $24.5 \%$ respondents who were not willing to pay gave their reasons in the followup questions (Table 3). We assumed that some of the reasons provided by respondents not 
willing to pay for maintaining ecosystem services were considered as protest responses such as "The government or polluters should pay," "Lack of sufficient information to decide," and "Environment associations are not effective." Such responders represented $73.1 \%$ of the "no" responders and $17.9 \%$ of total responders.

Table 2. Descriptions and summary statistics of variables used in economicvaluation analyses.

\begin{tabular}{|c|c|c|c|c|c|}
\hline Variables & Description & Median & $\begin{array}{l}\text { Mean } \\
\text { (std. dev, }\end{array}$ & Min & Max \\
\hline Education level & $\begin{array}{l}\text { Highest level of academic education } \\
\text { completed (no schooling completed (1) } \\
\text { to doctorate degree (9)) }\end{array}$ & 7 & $6.99(1.43)$ & 3 & 9 \\
\hline Age & Respondent's age & 50 & $49.98(12.98)$ & 19 & 87 \\
\hline Income level & $\begin{array}{l}\text { Annual household income } \\
(<\$ 20,000(1) \text { to }>\$ 80,000(5))\end{array}$ & 4 & $4.03(1.28)$ & 1 & 5 \\
\hline Female & $\begin{array}{l}\text { If the respondent is female } \\
(=1 \text { yes; } 0 \text { otherwise })\end{array}$ & 1 & $0.36(0.48)$ & 0 & 1 \\
\hline Household size & Number of household members & 2 & $2.69(1.10)$ & 1 & 6 \\
\hline Hispanic & $\begin{array}{l}\text { If the respondent is Hispanic } \\
\text { (=1 yes; } 0 \text { otherwise })\end{array}$ & 0 & $0.26(0.44)$ & 0 & 1 \\
\hline Resident & $\begin{array}{l}\text { If the respondent lives in the basin } \\
\quad(1=\text { yes; } 0 \text { otherwise })\end{array}$ & 1 & $0.67(0.47)$ & 0 & 1 \\
\hline Grandparent & $\begin{array}{l}\text { If the respondent's grandparents come from } \\
\text { the basin }(1=\text { yes; } 0 \text { otherwise })\end{array}$ & 0 & $0.34(0.48)$ & 0 & 1 \\
\hline Association & $\begin{array}{l}\text { If the respondent is a member in any } \\
\text { association, society, or other organization (1 } \\
\text { = yes; } 0 \text { otherwise) }\end{array}$ & 1 & $0.69(0.47)$ & 0 & 1 \\
\hline Community & $\begin{array}{l}\text { If the respondent participates in any } \\
\text { community activities ( } 1=\text { yes; } 0 \text { otherwise })\end{array}$ & 1 & $0.82(0.39)$ & 0 & 1 \\
\hline Drought & $\begin{array}{l}\text { If the respondent realizes negative impacts } \\
\text { of drought on water flow } \\
(1=\text { yes; } 0 \text { otherwise })\end{array}$ & 1 & $0.67(0.47)$ & 0 & 1 \\
\hline Upstream & $\begin{array}{l}\text { If the respondent realizes negative impacts } \\
\text { of upstream water use on water flow } \\
\text { ( } 1 \text { = yes; } 0 \text { otherwise })\end{array}$ & 1 & $0.61(0.49)$ & 0 & 1 \\
\hline $\begin{array}{l}\text { Ecosystem perception (fresh } \\
\text { water) }\end{array}$ & $\begin{array}{l}\text { Perception of the importance of freshwater } \\
\text { supplies in the basin (least important (1) } \\
\text { to most important (5)) }\end{array}$ & 5 & $4.74(0.82)$ & 1 & 5 \\
\hline $\begin{array}{l}\text { Ecosystem perception } \\
\quad \text { (culture heritage) }\end{array}$ & $\begin{array}{l}\text { Perception of the importance of cultural } \\
\text { heritage in the basin (least important (1) } \\
\text { to most important (5)) }\end{array}$ & 4 & $3.58(1.08)$ & 1 & 5 \\
\hline $\begin{array}{l}\text { Ecosystem perception (habitat } \\
\text { for wildlife) }\end{array}$ & $\begin{array}{l}\text { Perception of the importance of habitat for } \\
\text { wildlife in the basin (least important (1) to } \\
\text { most important (5)) }\end{array}$ & 4 & $4.12(0.90)$ & 1 & 5 \\
\hline $\begin{array}{l}\text { Ecosystem perception } \\
\text { (recreation) }\end{array}$ & $\begin{array}{l}\text { Perception of the importance of recreational } \\
\text { activities in the basin } \\
\text { (least important (1) to most important (5)) }\end{array}$ & 4 & $3.47(1.09)$ & 1 & 5 \\
\hline Time & $\begin{array}{l}\text { Duration (in minutes) of finishing the } \\
\text { online survey }\end{array}$ & 1.69 & $18.96(130.19)$ & 1.52 & 1306.17 \\
\hline Location_Lat & Latitude of respondent's location & 35.07 & $33.71(5.75)$ & 18.87 & 44.24 \\
\hline Location_Lon & Longitude of respondent's location & -105.32 & $-104.09(8.77)$ & -155.14 & -73.99 \\
\hline
\end{tabular}


Table 3. Numbers and reasons for respondents who were not willing to pay.

\begin{tabular}{ccccc}
\hline Reasons for Non-WTP & Number of Responders & $\begin{array}{c}\text { \% in Non-WTP } \\
\text { Responders }\end{array}$ & $\begin{array}{c}\text { \% in Overall } \\
\text { Sample }\end{array}$ & Responder Type \\
\hline Government/polluters should pay & 9 & $34.6 \%$ & $8.5 \%$ & Protest \\
Lack of sufficient & 5 & $19.2 \%$ & $4.7 \%$ & Protest \\
information/details to decide & & $19.2 \%$ & $4.7 \%$ & Protest \\
Environment associations are not & 5 & $11.5 \%$ & $2.8 \%$ & True zero \\
effective/trustable & 3 & $7.7 \%$ & $1.9 \%$ & True zero \\
I am not a resident of the basin & 2 & $7.7 \%$ & $1.9 \%$ & True zero \\
I cannot afford it & 2 & & & \\
Other & & & & \\
\hline
\end{tabular}

\subsection{Perceptions about Water Issues and Ecosystem Services in the US Rio Grande Basin}

Around $67 \%$ of survey respondents were residents in the Rio Grande Basin, and $34 \%$ had parents or grandparents living in this region. Those numbers could suggest that many respondents have high awareness of the water issues and changes in ecosystem services in the basin and therefore a good understanding of the necessity to conserve water resources. Figure 2 shows that most respondents identified water availability as the most-urgent issue in the basin region (rank five on the one to five Likert scale), followed by ecosystem conservation necessity (53.8\% respondents) and the water-quality issue (50.9\% respondents). Water-rights issues and recreational activities were ranked by most respondents as the least-relevant issues in the river basin.

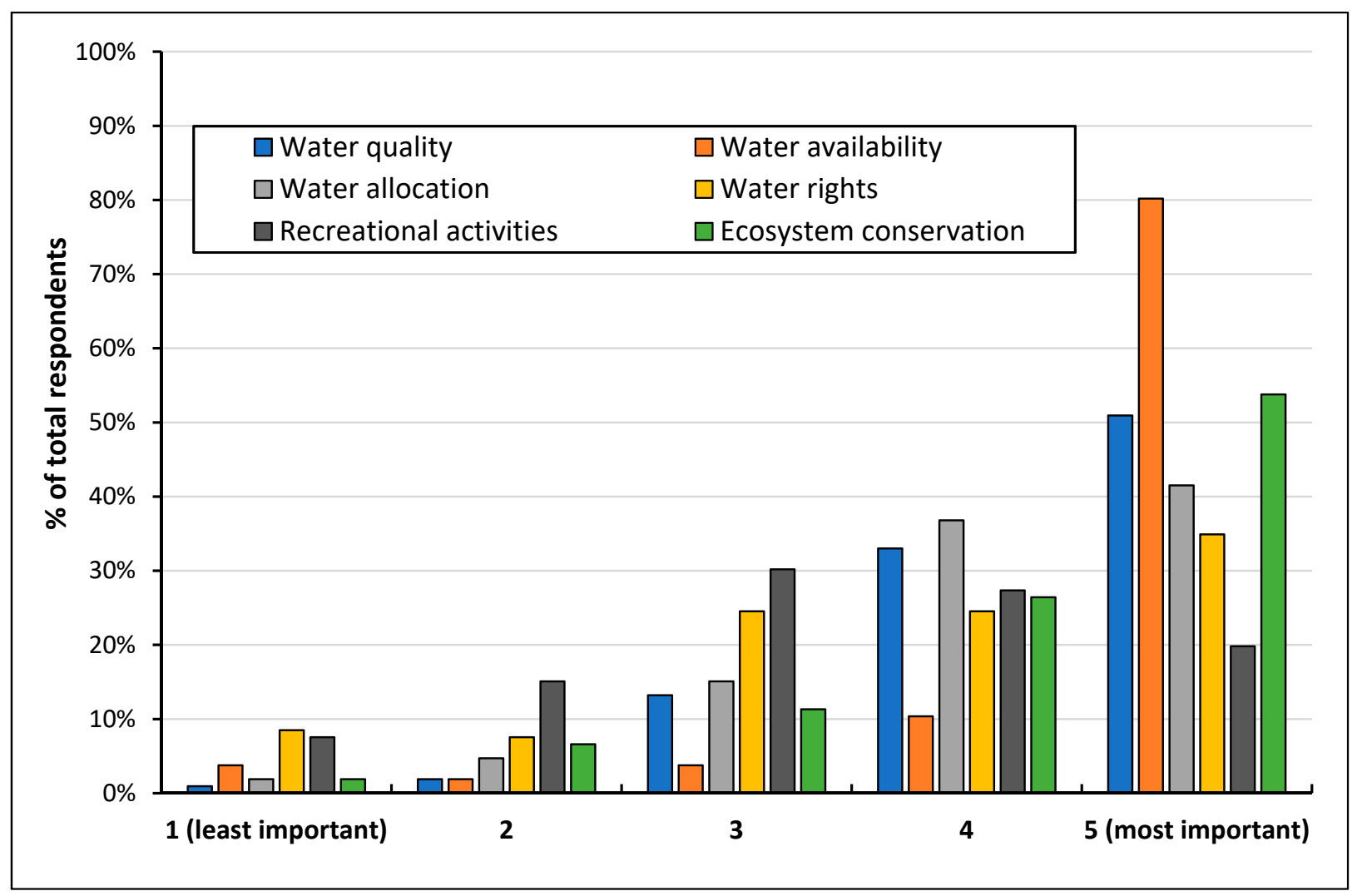

Figure 2. Percentage of respondents' perceptions about the importance of various water issues in the Rio Grande Basin $(\mathrm{N}=106)$. Importance level increases from 1 to $5 ; 1$ represents least important, and 5 represents most important. 
Different perceptions about water issues were found to directly translate to different preferences regarding the provision of ecosystem services. While most respondents acknowledged the provision of ecosystem services as relevant, they mentioned to have noticed a decrease in those services in the past 10 years. Among the four analyzed ecosystem services (freshwater supplies, habitat for wildlife, cultural heritage, and recreational activities), $84 \%$ of respondents ranked "freshwater supplies" as the most important concern and identified it as the most decreased ecosystem service in the last decade. Decreases in "habitat for wildlife," "cultural heritage," and "recreational activities" were classified as the most relevant/urgent by 54.7, 22.6, and $19.8 \%$ of the respondents, respectively. The respondents' perceptions about the importance of freshwater supplies and conservation of habitat for wildlife as the most-relevant ecosystem services aligned with their assessment about the most-drastic decrease rates. However, the assessment of decreasing recreational activities (41 respondents) in the past decade outranked that of cultural heritage (35 respondents) (Figures 3 and 4). This diverging assessment can be explained by the intangibility of "cultural heritage" as an ecosystem service and changes to its provision. While it is relatively uncomplicated to detect changes in visitation numbers based merely on observational perceptions (without scientific evaluations), it is challenging to detect and measure a change about "cultural heritage" provided by the Basin. However, the relatively high number of respondents emphasizing changes in this particular ecosystem service underscores solid knowledge of the respondents about the river basin and the broader picture of water-related issues, as described above.

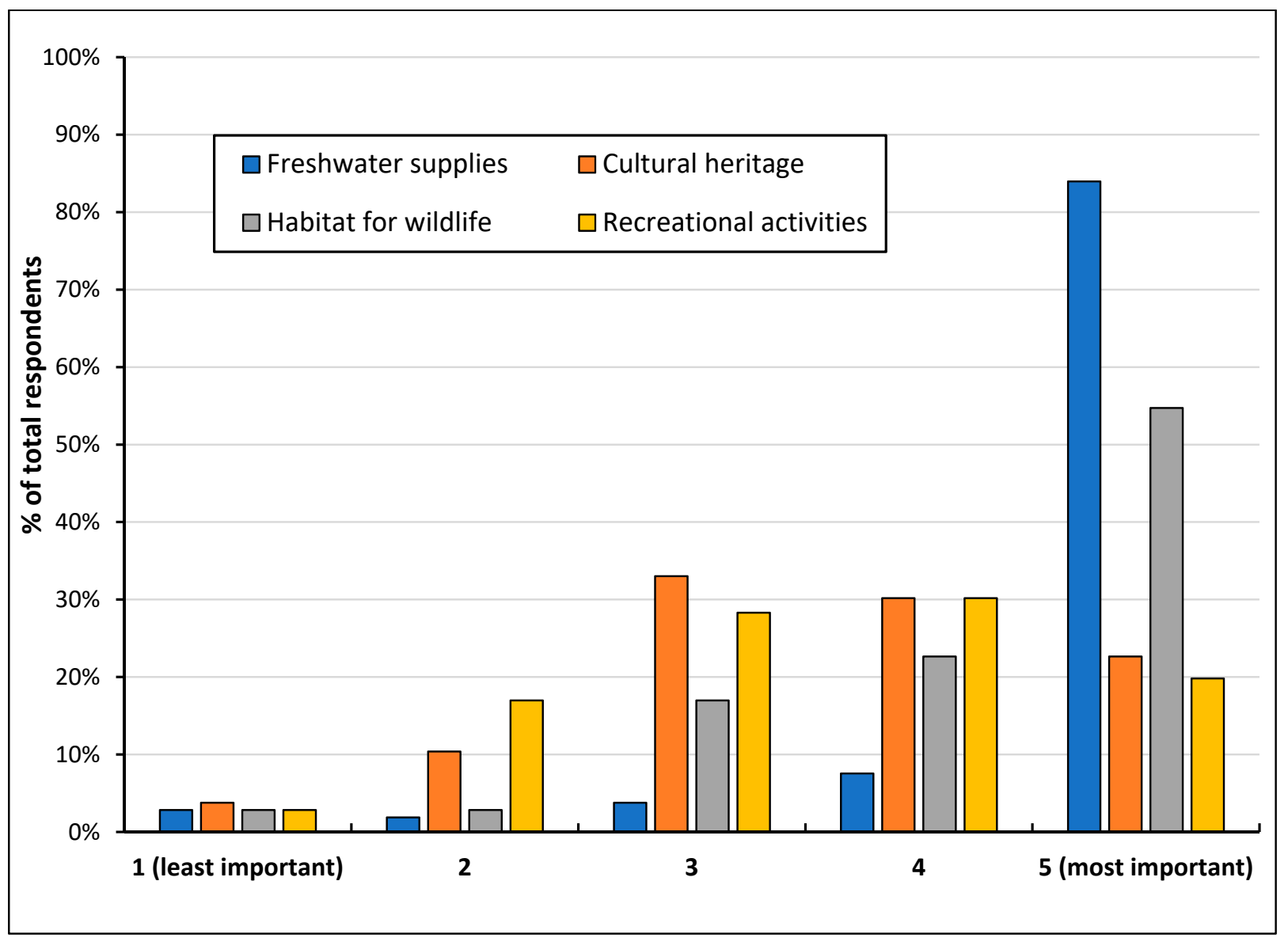

Figure 3. Percentage of respondents' perceptions about the importance of four ecosystem service provisions in the Rio Grande Basin $(\mathrm{N}=106)$. Importance level increases from 1 to $5 ; 1$ represents least important, and 5 represents most important. 


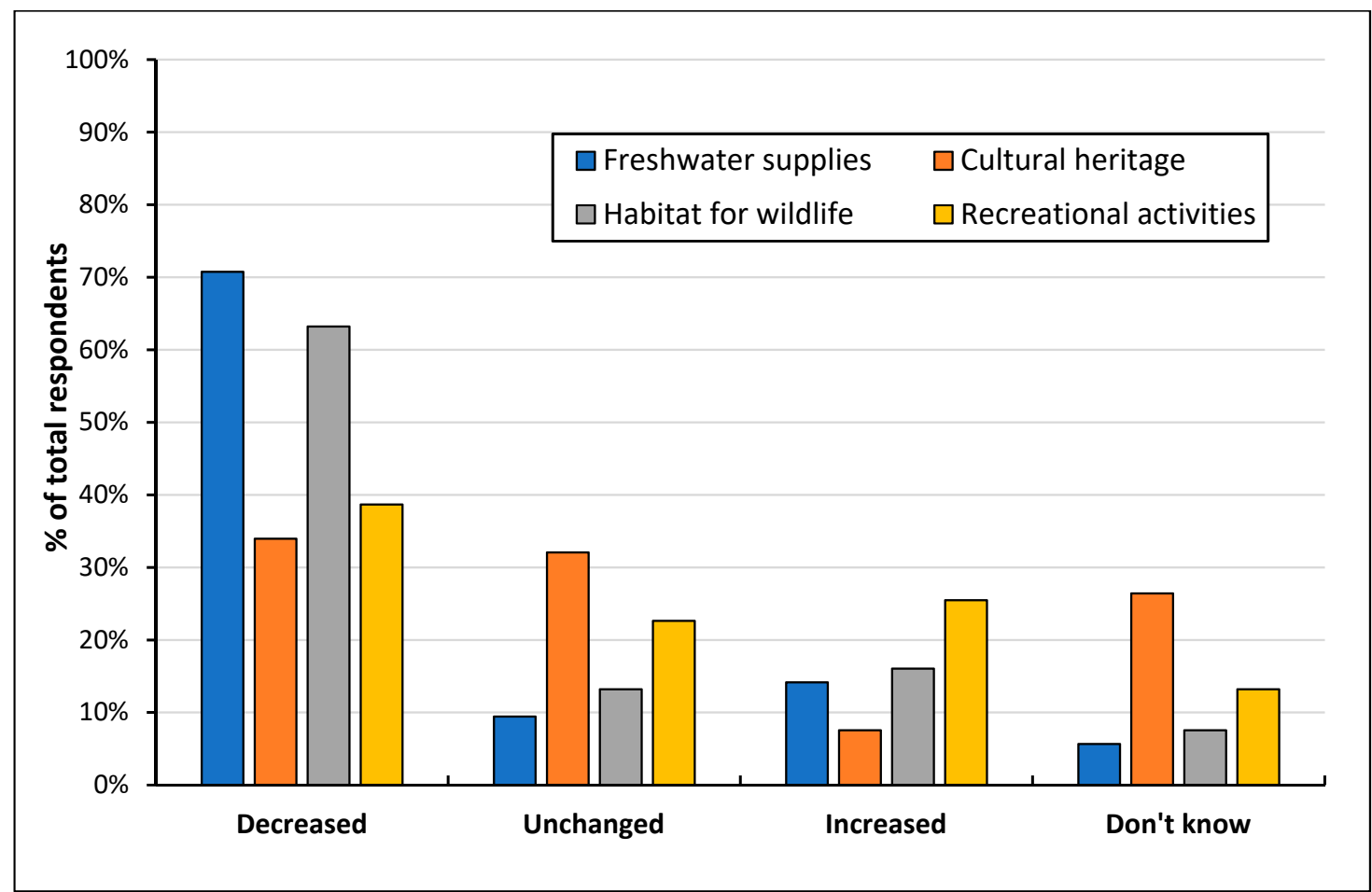

Figure 4. Percentage of respondents' perceptions about the benefits provided by the Rio Grande Basin over the last 10 years $(\mathrm{N}=106)$.

Tracking back the reasons of changes in ecosystem service provision in the basin, a positive association was found between changes in water flows and the provision of ecosystem services, which indicates that increased water flows would result in a higher provision of ecosystem services (Figure 5). However, the plurality of the respondents believed that drought and upstream water use decreased water flow in the basin over the past 10 years (Figure 6).

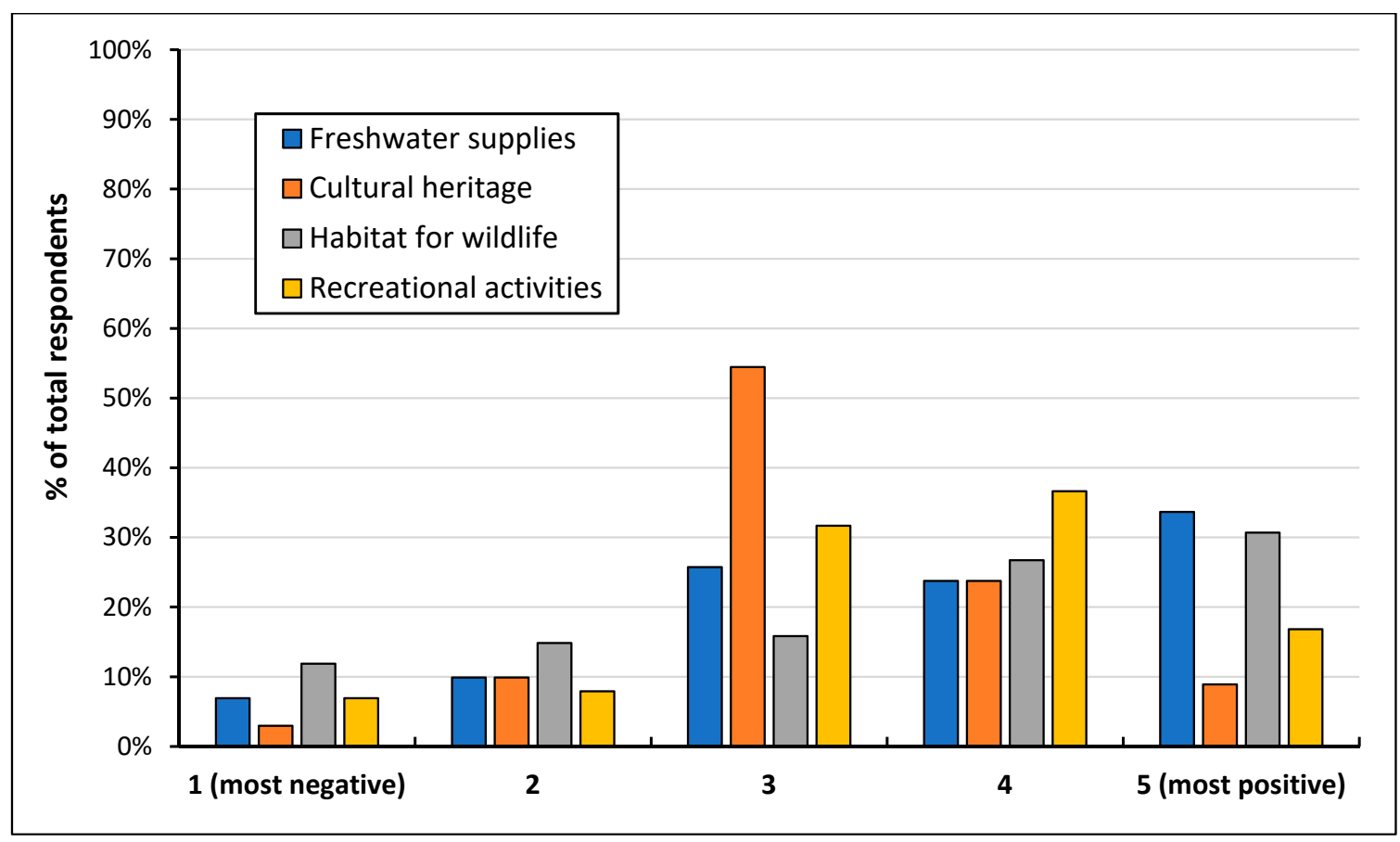

Figure 5. Percentage of respondents' perceptions about the impact of water flows on the provision of ecosystem services in the Rio Grande Basin $(\mathrm{N}=106) ; 1$ represents the most negative, and 5 represents the most positive. 


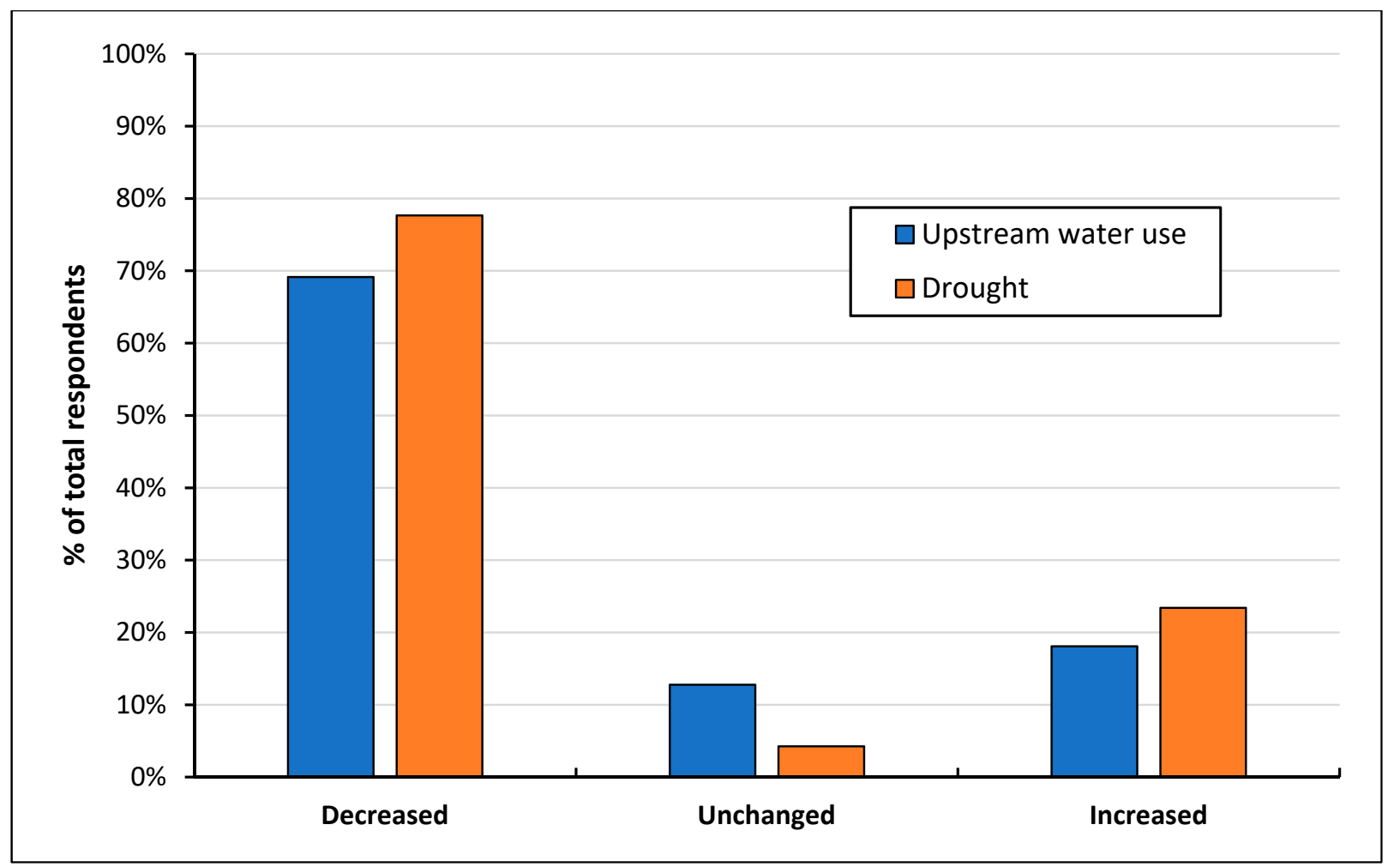

Figure 6. Percentage of respondents' perceptions about the effect of upstream water use and drought on stream flows over the past 10 years in the Rio Grande Basin $(\mathrm{N}=106)$.

\subsection{Factors Affecting Willingness-to-Pay in the Rio Grande Basin}

The factors affecting the willingness-to-pay for maintaining ecosystem services in the basin were determined with the Heckman sample selection model (Table 4). The inverse Mills ratio is insignificant and implies no serious concerns with sample-selection bias.

Regarding the results of the selection-model estimation, the outcomes show that several factors affect respondents' decisions on whether to support maintenance and provision of ecosystem services. Generally, respondents with higher education levels, respondents of Hispanic origin, residents living in the Rio Grande Basin, and respondents with parents/grandparents living outside of the basin region are more inclined to support the maintenance and provision of ecosystem services, thus indicating a higher frequency and probability of willingness-to-pay in general terms.

Accordingly, with an increase in respondents' education level (from each given level of education to a next higher level of education as specified in the survey), the probability of the general decision about contributing financially to the maintenance of ecosystem services would increase by $54.5 \%$. Hispanic ethnicity of the respondents would indicate a higher probability of their positive decision to support the maintenance of ecosystem services financially, compared to other ethnicities. Similarly, residents of the basin were found to have a higher probability for willingness to pay for ecosystem service maintenance. However, if the respondents' parents / grandparents are residents in the basin, the probability of the respondents' decision to contribute to ecosystem service maintenance financially would decrease. 
Table 4. Estimates from the Heckman two-step model $(\mathrm{N}=106)$.

\begin{tabular}{|c|c|c|c|c|c|c|}
\hline \multirow[b]{2}{*}{ Variables } & \multirow{2}{*}{$\begin{array}{c}\text { Selection Equation } \\
\mathrm{Zi}\end{array}$} & \multicolumn{5}{|c|}{ Outcome Equation } \\
\hline & & Total WTP & $\begin{array}{l}\text { Freshwater } \\
\text { Supplies }\end{array}$ & $\begin{array}{l}\text { Culture } \\
\text { Heritage }\end{array}$ & $\begin{array}{c}\text { Habitat } \\
\text { for Wildlife }\end{array}$ & $\begin{array}{c}\text { Recreational } \\
\text { Activities }\end{array}$ \\
\hline $\begin{array}{c}\text { Education level } \\
\text { (low (1) to high (9)) }\end{array}$ & $\begin{array}{c}0.5445^{* * *} \\
(0.2049)\end{array}$ & $\begin{array}{l}-0.0747 \\
(0.1521)\end{array}$ & $\begin{array}{c}0.5451 \\
(1.3794)\end{array}$ & $\begin{array}{c}0.6189 \\
(0.7752)\end{array}$ & $\begin{array}{c}0.7180 \\
(0.9777)\end{array}$ & \\
\hline Age & $\begin{array}{l}-0.0302 \\
(0.0184)\end{array}$ & $\begin{array}{l}-0.0106 \\
(0.0150)\end{array}$ & $\begin{array}{l}-0.1176 \\
(0.1262)\end{array}$ & $\begin{array}{l}-0.1721^{* *} \\
(0.0889)\end{array}$ & $\begin{array}{l}-0.1482 * \\
(0.0836)\end{array}$ & $\begin{array}{c}-0.1742 * * \\
(0.0791)\end{array}$ \\
\hline $\begin{array}{c}\text { Income level } \\
\text { (low (1) to high (5)) }\end{array}$ & & $\begin{array}{c}0.4359^{* * *} \\
(0.1165)\end{array}$ & & $\begin{array}{c}0.4685 \\
(0.8195)\end{array}$ & & \\
\hline whether is female & $\begin{array}{l}-0.3705 \\
(0.4640)\end{array}$ & $\begin{array}{l}0.0250 \\
(0.2747)\end{array}$ & $\begin{array}{l}-2.3930 \\
(2.4866)\end{array}$ & & $\begin{array}{l}-1.2943 \\
(1.7501)\end{array}$ & \\
\hline Household size & $\begin{array}{c}0.2296 \\
(0.1890)\end{array}$ & $\begin{array}{l}-0.1308 \\
(0.1272)\end{array}$ & & $\begin{array}{c}0.2823 \\
(0.8787)\end{array}$ & $\begin{array}{l}-0.3456 \\
(0.8201)\end{array}$ & \\
\hline Whether is Hispanic & $\begin{array}{c}1.8694^{* * *} \\
(0.6179)\end{array}$ & $\begin{array}{l}0.4801 \\
(0.5375)\end{array}$ & $\begin{array}{c}4.3299 \\
(4.1547)\end{array}$ & & $\begin{array}{l}-0.1461 \\
(3.2224)\end{array}$ & \\
\hline Whether is resident & $\begin{array}{l}1.3458^{* * *} \\
(0.4706)\end{array}$ & $\begin{array}{l}0.4592^{* * *} \\
(0.1182)\end{array}$ & $\begin{array}{l}1.9269 * * * \\
(0.4070)\end{array}$ & & $\begin{array}{l}2.1885^{*} \\
(1.3067)\end{array}$ & \\
\hline $\begin{array}{l}\text { Whether grandparents } \\
\text { are residents }\end{array}$ & $\begin{array}{c}-1.7290^{* * *} \\
(0.4539)\end{array}$ & $\begin{array}{l}-0.1894 \\
(0.5584)\end{array}$ & $\begin{array}{c}-9.1419 * * \\
(4.5451)\end{array}$ & & $\begin{array}{l}-1.9021 \\
(3.4607)\end{array}$ & \\
\hline $\begin{array}{l}\text { Whether is } \\
\text { association member }\end{array}$ & $\begin{array}{l}0.3480 \\
(0.4772)\end{array}$ & $\begin{array}{l}0.1197 \\
(0.2779)\end{array}$ & $\begin{array}{l}2.5475 \\
(2.5723)\end{array}$ & & & \\
\hline $\begin{array}{l}\text { Whether participating } \\
\text { in community activities }\end{array}$ & $\begin{array}{c}0.2896 \\
(0.5710)\end{array}$ & $\begin{array}{c}0.0999 \\
(0.3913)\end{array}$ & & $\begin{array}{c}3.2655 \\
(2.6001)\end{array}$ & $\begin{array}{c}2.4050 \\
(2.3938)\end{array}$ & $\begin{array}{l}3.2468 \\
(2.7914)\end{array}$ \\
\hline $\begin{array}{l}\text { Whether realizing negative } \\
\text { impacts of drought } \\
\text { on water flow }\end{array}$ & $\begin{array}{c}0.2069 \\
(0.3833)\end{array}$ & $\begin{array}{c}0.2950 \\
(0.2431)\end{array}$ & & & $\begin{array}{c}2.3641 \\
(1.7562)\end{array}$ & \\
\hline $\begin{array}{l}\text { Whether realizing negative } \\
\text { impacts of upstream } \\
\text { water use on water flow }\end{array}$ & & & & & $\begin{array}{c}1.2158 \\
(1.7785)\end{array}$ & \\
\hline $\begin{array}{l}\text { Importance of } \\
\text { ecosystem services }\end{array}$ & & & $2.4575 * *$ & $3.0064^{* * *}$ & $2.1231 * * *$ & $2.7834 * * *$ \\
\hline $\begin{array}{l}\text { Time to finishing } \\
\text { the online survey }\end{array}$ & -0.0016 & -0.0016 & $\begin{array}{c}(1.0165) \\
0.0104\end{array}$ & $(0.7511)$ & $\begin{array}{l}(0.6786) \\
-0.0078\end{array}$ & $(0.8038)$ \\
\hline & $(0.0022)$ & $(0.0028)$ & $(0.0258)$ & & $(0.0172)$ & \\
\hline $\begin{array}{c}\text { Respondents' } \\
\text { location latitude }\end{array}$ & $0.0841^{*}$ & -0.0326 & 0.0579 & & 0.2208 & 0.0946 \\
\hline $\begin{array}{l}\text { Respondents' } \\
\text { location longitude }\end{array}$ & $\begin{array}{l}(0.0429) \\
-0.0217\end{array}$ & $\begin{array}{c}(0.0269) \\
0.0047\end{array}$ & $(0.2506)$ & -0.0935 & $\begin{array}{l}(0.1739) \\
-0.0833\end{array}$ & $\begin{array}{l}(0.1727) \\
-0.1083\end{array}$ \\
\hline $\begin{array}{l}\text { Constant } \\
\text { Mills lambda }\end{array}$ & $\begin{array}{c}(0.0236) \\
-8.2704 * * \\
(3.4854)\end{array}$ & $\begin{array}{c}(0.0127) \\
2.0182 * * * \\
(0.6507) \\
0.4915 \\
(1.0091)\end{array}$ & $\begin{array}{c}-6.6140 * * \\
(3.1066) \\
9.1608 \\
(7.4524)\end{array}$ & $\begin{array}{c}(0.0938) \\
-26.0853 \\
(18.0388) \\
-1.6139 \\
(3.6294)\end{array}$ & $\begin{array}{c}(0.0822) \\
-16.7574 \\
(13.3268) \\
5.8926 \\
(6.0775)\end{array}$ & $\begin{array}{c}(0.1005) \\
-24.3879 \\
(20.1037) \\
3.6748 \\
(3.8510)\end{array}$ \\
\hline
\end{tabular}

Note: standard errors in parentheses; ${ }^{*} p<0.1,{ }^{* *} p<0.05$ and ${ }^{* * *} p<0.01$.

As to the results of the second model estimation (outcome equation), several factors were found to affect the economic value assigned to the respective ecosystem services, although considerable differences were detected in the estimates for the different types of the ecosystem services. The following statements can be derived from the statistical analyses of the respective ecosystem services groups:

(1) Regarding the WTP for all ecosystem services combined, the income level and residence of respondents in the region are positively related to the amount of money the respondents would be willing to pay. Accordingly, the higher income level would result in the higher WTP. People living in the basin area were more likely to favor a higher level of financial support for ecosystem services.

(2) In regard to the payments for freshwater supplies, whether the respondent is a resident has a positive impact on the mean WTP, whereas having parents or grandparents living in the basin region has opposite effects.

(3) In regard to cultural heritage, older respondents indicated a lower WTP for maintenance of this ecosystem service. The respondents who gave more on the importance of cultural heritage provided by the basin were more willing to increase their WTP for maintaining this service. 
(4) In regard to habitat for wildlife, the model results show that younger respondents and residents of the basin region would be willing to pay more for conserving habitat for wildlife than the rest of the respondents.

(5) In regard to maintaining recreational activities, the same two variables were found to be statistically significant as in the model of culture heritage, which could indicate that recreational activities are viewed similarly as the benefits provided by culture heritage. Younger people and people who have knowledge about the importance of recreational activities were more likely to donate more money.

\subsection{Willingness-to-Pay for Preserving Ecosystem Services in the Rio Grande Basin}

The WTP for ecosystem service provided by the basin was found to average at USD 62 as an annual donation. Depending on the respondents' perceptions about the provision of ecosystem services, a wide variability in their willingness-to-pay for each type of the ecosystem services was found, ranging between USD 0 and 250 for the total of ecosystem services provided by the basin, with a median of USD 50/year (Figure 7). "Habitat for wildlife" received the highest mean WTP (USD 26.2/year) compared to the other three groups of ecosystem services. "Freshwater supplies" received the second-highest mean WTP (USD 19.7/year) in annual donations. These findings are consistent with the results presented in Figures 2-4, showing that the respondents would be willing to pay more for the river ecosystem services they find most relevant for the Rio Grande Basin, mostly affected by upstream water use and drought over the past decade.

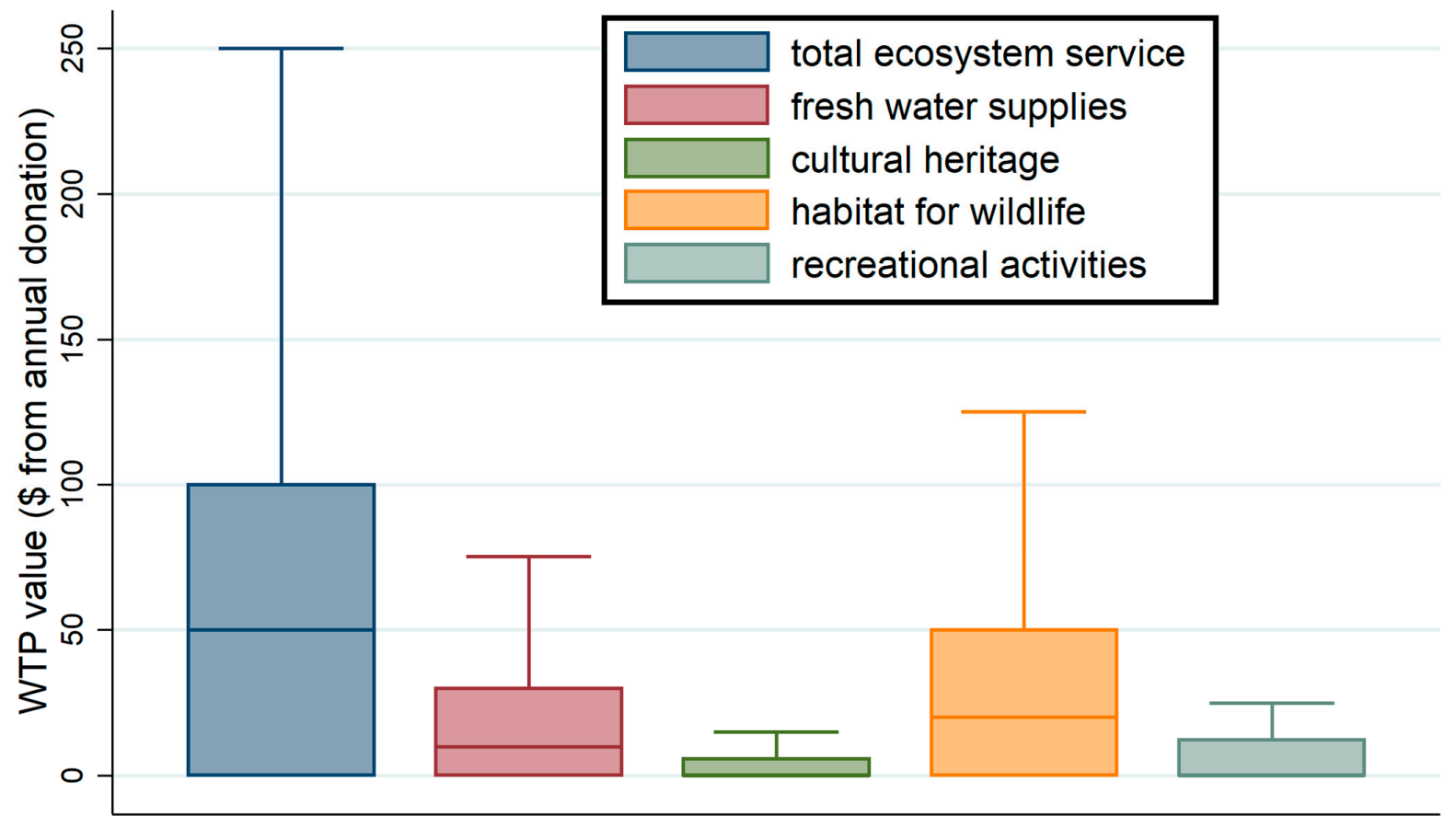

Figure 7. Distributions of WTP value of total ecosystem service and WTP values across four types of ecosystem services in the Rio Grande Basin $(\mathrm{N}=106)$.

Interestingly though, the WTP for conserving the habitat for wildlife was ranked higher than for freshwater supplies. It can be deduced that most respondents associate a donation as a valid support form mainly for cultural, regulating, or supporting ecosystem services rather than provisioning ecosystem services (like freshwater supplies) that humans rightly understand as one of the basic and essential rights to live. Additionally, since water is a common good, humans tend to anticipate a secured access to water without the necessity to pay additional fees towards water provision. 


\section{Discussion}

Sustaining healthy freshwater ecosystems is a global challenge, especially with increasing population and climate change $[37,38]$. Deterioration of ecological services caused by human activities and changing climate has severely threatened the food safety, human health, and sustainable development of watersheds in the US and many other countries [7,26,38-40]. Ecosystem services that contribute directly to human well-being are increasingly being taken into consideration in decision-making processes and in international studies, treaties, and conventions [41-43]. Simply classifying services is insufficient for informing policy. Understanding the benefits and economic value that people get from ecosystems is essential for making water-management strategies and policy decisions. This study applied a contingent valuation method to identify social preferences and WTP for preserving watershed ecosystem services in the Rio Grande Basin.

Among the investigated ecosystem services in this study, freshwater supplies were recognized as the-most important issue and the most-decreased ecosystem service in the last decade. This implies that most people prioritize services that directly affect human health and local economies such as drinking water, farming, and fishing. This perception is largely consistent with other residents' preferences revealed in global watershed studies [2,39,44]. Among the four analyzed ecosystem services, cultural heritage and recreational activities were judged the least important. These findings suggest that local managers and policy makers aiming at improving the watershed services should prioritize managing or allocating resources between competing demands and sustainable freshwater supplies.

The total economic value estimated for watershed services was found to average at USD 62 per household per year and an average of USD 12.4 per ecosystem service. Our mean WTP value was comparable to many other WTP exercises performed in the US and global watersheds. Weber and Stewart [26] estimated public values for river restoration on the Middle Rio Grande, New Mexico. Full restoration benefits were found at nearly USD 50 per household per year via contingent valuation. Castro et al. [2] targeted multiple stakeholders' social perception regarding various categories of ecosystem services in the Kiamichi River watershed in south central Oklahoma. The authors found the average WTP was USD 50 per household per year for all ecosystem services. Similarly, Lewis et al. [28] found that residents were willing to pay an average of USD 80 for the ecological services provided by riparian zones in an Ozark watershed located in Northwest Arkansas. The high variability of the WTP for the respective ecosystem services reflects the heterogenous perspectives towards the value provided by the watershed. The revealed average amount of respondents' WTP for each ecosystem service was limited and even less than a meal at a restaurant. This suggests that people tend to anticipate the government's or community's initiatives in securing the freshwater provision and habitat for wildlife. The relatively low WTP for cultural services indicates the fact that the enjoyment of outdoor activities and appreciation of beautiful natural areas in the basin are not as crucial as freshwater demand to human beings.

The positive and significant determinants of WTP found in this study were respondents' income and residence in the Rio Grande area. Education level and watershed residence were also among factors that positively related to the probability of participating in economic-valuation exercises. These findings corroborate previous WTP literature on the importance of knowledge and direct experience in shaping respondents' WTP [45,46]. Intuitively, people with higher income were more responsive to providing financial support for maintaining ecosystem services. Watershed residents were also more willing to pay for preserving watershed services than nonresidents, which may be related to a greater concern and appreciation of the interdependence between environment and well-being. However, the parents/grandparents' residence in the basin was found to be negatively related to the WTP decision, which was also confirmed in other studies as well [2]. This counterintuitive outcome can be possibly explained by an implicit perception of the respondents that their parents and grandparents have already contributed to those ecosystem services in the past, thus their personal obligations could be lightened. Some studies $[2,19]$ have also found 
that other factors have significant impacts on WTP such as environmental-association members and a perception of government influence, but others, including this study, show the effects of these variables to be insignificant. From a water-management perspective, the findings suggest that appropriate education and community involvement with all levels' stakeholders are a useful tool in building commitment and willingness for change.

While economic incentives are not the panacea to solve the complex environmental issues, the estimates of perceived economic value delivered in this study can be used as an additional tool to other instruments. For example, for the decision to implement the water conservation project in the Rio Grande region, the aggregated value estimated from the public's WTP should be compared to the total cost as a means to explore the social desirability of the project. The integrative coupling of social-cultural valuation, economic assessment, and political instruments is important for sustaining ecosystem services [44].

\section{Conclusions}

In this study, a contingent-valuation methodology was applied to determine the willingness-to-pay and the corresponding economic value of ecosystem services provided by the Rio Grande Basin in three US states (Colorado, New Mexico, and Texas).

The average WTP for all analyzed ecosystem services amounted to USD 62/year, while most respondents assigned a higher economic value to the conservation of habitat for wildlife and the provision of freshwater supplies.

The results show that respondents with higher education levels, of Hispanic ethnicity, living in the Rio Grande Basin, and respondents with parents/grandparents living outside of the Rio Grande region are generally more inclined to support the maintenance and provision of ecosystem services. However, the economic value they assigned to each of the ecosystem services varies among the ecosystem-services groups and depends on several socio-economic characteristics of the survey respondents. The average WTP for fresh water supplies amounted to USD 19.7/year, USD 7.1/year for cultural heritage, USD 26.2/year for maintaining the habitat for wildlife, and USD 8.1/year for recreational activities.

Although this study is empirical and exploratory, the methodology can be recommended as a tool for interactive decision-making and round-table discussions among decision makers, stakeholders, water utilities, water-conservation offices, representatives from different economic sectors, and local communities. This would be especially valuable for the broader question at hand as the basin is split among three US states with different water jurisdictions, regulations, and laws, which makes water management quite challenging across the entire basin. Utilizing a holistic methodology, widely validated and acknowledged in scientific circles, could prove helpful with finding a common ground and a prospective direction for the design of water-conservation measures, both on the demand and the supply side. It could also be utilized to compare different water-conservation strategies in place and potential new technologies in terms of their economic efficiency, environmental sustainability, and social acceptance and equity.

More research is necessary to address the specific ecosystem-services issues of specific community or social groups. In addition, a county-, state-, and river-section-level differentiation of the WTP for the ecosystem services would be of particular interest to the research community and stakeholders. We leave these explorations to future work.

Author Contributions: Conceptualization and methodology, W.W., J.E.M. and J.R.Z.; data collection, J.E.M.; formal analysis, W.W. and J.E.M.; writing—original draft preparation, J.E.M.; writing—review and editing, W.W. and J.R.Z.; project administration, J.R.Z.; funding acquisition, J.R.Z. and W.W. All authors have read and agreed to the published version of the manuscript.

Funding: This work was funded by the US Geological Survey (Grant \#: G15AP00132, 2015) and the Startup Foundation for Introducing Talent of NUIST.

Institutional Review Board Statement: The study was approved by the Institutional Review Board of University of Oklahoma. Approval Code: 7924; Approval Date: 5 August 2017.

Informed Consent Statement: Informed consent was obtained from all subjects involved in the study. 
Data Availability Statement: Raw data in this study is not publicly available due to privacy/ ethical restrictions.

Acknowledgments: The authors would like to thank the survey participants for their support of the project. The authors would also like to acknowledge the anonymous reviewers for their constructive comments that improved the manuscript.

Conflicts of Interest: The authors declare no conflict of interest.

\section{References}

1. Millennium Ecosystem Assessment. Ecosystems and Human Well-Being: Synthesis; Island Press: Washington, DC, USA, 2005.

2. Castro, A.J.; Vaughn, C.C.; García-Llorente, M.; Julian, J.P.; Atkinson, C.L. Willingness to Pay for Ecosystem Services among Stakeholder Groups in a South-Central U.S. Watershed with Regional Conflict. J. Water Resour. Plan. Manag. 2016, 142, 05016006. [CrossRef]

3. Spash, C.L.; Urama, K.; Burton, R.; Kenyon, W.; Shannon, P.; Hill, G. Motives behind Willingness to Pay for Improving Biodiversity in a Water Ecosystem: Economics, Ethics and Social Psychology. Ecol. Econ. 2009, 68, 955-964. [CrossRef]

4. Johnson, N.L.; Baltodano, M.E. The Economics of Community Watershed Management: Some Evidence from Nicaragua. Ecol. Econ. 2004, 49, 57-71. [CrossRef]

5. Loomis, J.B. Environmental Valuation Techniques in Water Resource Decision Making. J. Water Resour. Plan. Manag. 2000, 126, 339-344. [CrossRef]

6. Thapa, S.; Wang, L.; Koirala, A.; Shrestha, S.; Bhattarai, S.; Aye, W.N. Valuation of Ecosystem Services from an Important Wetland of Nepal: A Study from Begnas Watershed System. Wetlands 2020, 40, 1071-1083. [CrossRef]

7. Bhandari, P.; Kc, M.; Shrestha, S.; Aryal, A.; Shrestha, U.B. Assessments of Ecosystem Service Indicators and Stakeholder's Willingness to Pay for Selected Ecosystem Services in the Chure Region of Nepal. Appl. Geogr. 2016, 69, 25-34. [CrossRef]

8. Mwebaze, P.; Marris, G.C.; Brown, M.; MacLeod, A.; Jones, G.; Budge, G.E. Measuring Public Perception and Preferences for Ecosystem Services: A Case Study of Bee Pollination in the UK. Land Use Policy 2018, 71, 355-362. [CrossRef]

9. Ren, Y.; Lu, L.; Zhang, H.; Chen, H.; Zhu, D. Residents' Willingness to Pay for Ecosystem Services and Its Influencing Factors: A Study of the Xin'an River Basin. J. Clean. Prod. 2020, 268, 122301. [CrossRef]

10. Sehreen, F.; Masud, M.M.; Akhtar, R.; Masum, M.R.A. A Contingent Valuation Approach to Evaluating Willingness to Pay for an Improved Water Pollution Management System in Dhaka City, Bangladesh. Environ. Monit Assess. 2019, 191, 457. [CrossRef] [PubMed]

11. Koetse, M.J.; Brouwer, R.; van Beukering, P.J.H. Economic Valuation Methods for Ecosystem Services. In Ecosystem Services; Bouma, J.A., van Beukering, P.J.H., Eds.; Cambridge University Press: Cambridge, UK, 2015; pp. 108-131. ISBN 978-1-107-47761-2.

12. Loomis, J.; Santiago, L. Economic Valuation of Beach Quality Improvements: Comparing Incremental Attribute Values Estimated from Two Stated Preference Valuation Methods. Coast. Manag. 2013, 41, 75-86. [CrossRef]

13. Loomis, J.B. 2013 WAEA Keynote Address: Strategies for Overcoming Hypothetical Bias in Stated Preference Surveys. J. Agric. Resour. Econ. 2014, 39, 34-46.

14. Mitchell, R.C.; Carson, R.T. Using Surveys to Value Public Goods: The Contingent Valuation Method; Johns Hopkins University Press: Washington, DC, USA; Baltimore, MD, USA, 1989; ISBN 978-0-915707-32-4.

15. Meyerhoff, J.; Liebe, U. Determinants of Protest Responses in Environmental Valuation: A Meta-Study. Ecol. Econ. 2010, 70, 366-374. [CrossRef]

16. Desaigues, B.; Ami, D.; Bartczak, A.; Braun-Kohlová, M.; Chilton, S.; Czajkowski, M.; Farreras, V.; Hunt, A.; Hutchison, M.; Jeanrenaud, C.; et al. Economic Valuation of Air Pollution Mortality: A 9-Country Contingent Valuation Survey of Value of a Life Year (VOLY). Ecol. Indic. 2011, 11, 902-910. [CrossRef]

17. Jones, N.; Sophoulis, C.M.; Malesios, C. Economic Valuation of Coastal Water Quality and Protest Responses: A Case Study in Mitilini, Greece. J. Socio-Econ. 2008, 37, 2478-2491. [CrossRef]

18. Meyerhoff, J.; Mørkbak, M.R.; Olsen, S.B. A Meta-Study Investigating the Sources of Protest Behaviour in Stated Preference Surveys. Environ. Resour. Econ. 2014, 58, 35-57. [CrossRef]

19. O'Connor, E.; Hynes, S.; Chen, W. Estimating the Non-Market Benefit Value of Deep-Sea Ecosystem Restoration: Evidence from a Contingent Valuation Study of the Dohrn Canyon in the Bay of Naples. J. Environ. Manag. 2020, 275, 111180. [CrossRef] [PubMed]

20. Heckman, J. Sample Selection Bias as a Specification Error. Econometrica 1979, 47, 153-161. [CrossRef]

21. Garcia, S.; Harou, P.; Montagné, C.; Stenger, A. Models for Sample Selection Bias in Contingent Valuation: Application to Forest Biodiversity. JFE 2009, 15, 59-78. [CrossRef]

22. Osiolo, H.H. Willingness to Pay for Improved Energy: Evidence from Kenya. Renew. Energy 2017, 112, 104-112. [CrossRef]

23. Tan, R.; Lin, B. Public Perception of New Energy Vehicles: Evidence from Willingness to Pay for New Energy Bus Fares in China. Energy Policy 2019, 130, 347-354. [CrossRef]

24. Rister, M.E.; Sturdivant, A.W.; Lacewell, R.D.; Michelsen, A.M. Challenges and Opportunities for Water of the Rio Grande. J. Agric. Appl. Econ. 2011, 43, 367-378. [CrossRef] 
25. Raheem, N.; Archambault, S.; Arellano, E.; Gonzales, M.; Kopp, D.; Rivera, J.; Guldan, S.; Boykin, K.; Oldham, C.; Valdez, A.; et al. A Framework for Assessing Ecosystem Services in Acequia Irrigation Communities of the Upper Río Grande Watershed: A Framework for Assessing Ecosystem Services in Acequia Irrigation Communities. WIREs Water 2015, 2, 559-575. [CrossRef]

26. Weber, M.A.; Stewart, S. Public Values for River Restoration Options on the Middle Rio Grande. Restor. Ecol. 2009, 17, 762-771. [CrossRef]

27. Yoskowitz, D.W.; Montagna, P.A. Socio-Economic Factors That Impact the Desire to Protect Freshwater Flow in the Rio Grande, USA; Brebbia, C.A., Tiezzi, E., Eds.; Ecosystems and Sustainable Development VII; WIT Press: Chianciano Terme, Italy, 2009; pp. 547-558.

28. Lewis, S.E.; Popp, J.S.; English, L.A.; Odetola, T.O. Willingness to Pay for Riparian Zones in an Ozark Watershed. J. Water Resour Plann. Manag. 2017, 143, 04017006. [CrossRef]

29. Tentes, G.; Damigos, D. Discrete Choice Experiment for Groundwater Valuation: Case of the Asopos River Basin, Greece. J. Water Resour. Plan. Manag. 2015, 141, 04014089. [CrossRef]

30. Wainger, L.A.; King, D.M.; Mack, R.N.; Price, E.W.; Maslin, T. Can the Concept of Ecosystem Services Be Practically Applied to Improve Natural Resource Management Decisions? Ecol. Econ. 2010, 69, 978-987. [CrossRef]

31. Wainger, L.; Mazzotta, M. Realizing the Potential of Ecosystem Services: A Framework for Relating Ecological Changes to Economic Benefits. Environ. Manag. 2011, 48, 710. [CrossRef] [PubMed]

32. USGS. Monitoring the Water Quality of the Nation's Large Rivers: Rio Grande NASQAN Program. Fact Sheet. 1998. Available online: https: / pubs.usgs.gov/fs/1998/0083/report.pdf (accessed on 12 December 2021).

33. USGS. USGS Water Data for the Nation. Available online: https:/ /Waterdata.Usgs.Gov/nwis. (accessed on 1 September 2021).

34. Tibshirani, R. Regression Shrinkage and Selection Via the Lasso. J. R. Stat. Soc. Ser. B Methodol. 1996, 58, 267-288. [CrossRef]

35. Tibshirani, R. Regression Shrinkage and Selection via the Lasso: A Retrospective: Regression Shrinkage and Selection via the Lasso. J. R. Stat. Soc. Ser. B Stat. Methodol. 2011, 73, 273-282. [CrossRef]

36. Efron, B.; Hastie, T.; Johnstone, I.; Tibshirani, R. Least Angle Regression. Ann. Statist. 2004, 32, 407-499. [CrossRef]

37. Gleick, P.H. Transitions to Freshwater Sustainability. Proc. Natl. Acad. Sci. USA 2018, 115, 8863-8871. [CrossRef] [PubMed]

38. Retallack, M. The Intersection of Economic Demand for Ecosystem Services and Public Policy: A Watershed Case Study Exploring Implications for Social-Ecological Resilience. Ecosyst. Serv. 2021, 50, 101322. [CrossRef]

39. Ali, M.A.S.; Khan, S.U.; Khan, A.; Khan, A.A.; Zhao, M. Ranking of Ecosystem Services on the Basis of Willingness to Pay: Monetary Assessment of a Subset of Ecosystem Services in the Heihe River Basin. Sci. Total. Environ. 2020, 734, 139447. [CrossRef] [PubMed]

40. Castro, A.J.; Vaughn, C.C.; Julian, J.P.; García-Llorente, M. Social Demand for Ecosystem Services and Implications for Watershed Management. J. Am. Water Resour. Assoc. 2016, 52, 209-221. [CrossRef]

41. Förster, J.; Schmidt, S.; Bartkowski, B.; Lienhoop, N.; Albert, C.; Wittmer, H. Incorporating Environmental Costs of Ecosystem Service Loss in Political Decision Making: A Synthesis of Monetary Values for Germany. PLoS ONE 2019, 14, e0211419. [CrossRef] [PubMed]

42. Grêt-Regamey, A.; Altwegg, J.; Sirén, E.A.; van Strien, M.J.; Weibel, B. Integrating Ecosystem Services into Spatial Planning-A Spatial Decision Support Tool. Landsc. Urban Plan. 2017, 165, 206-219. [CrossRef]

43. Alexander, S.; Aronson, J.; Whaley, O.; Lamb, D. The Relationship between Ecological Restoration and the Ecosystem Services Concept. Ecol. Soc. 2016, 21, art34. [CrossRef]

44. Chaikaew, P.; Hodges, A.W.; Grunwald, S. Estimating the Value of Ecosystem Services in a Mixed-Use Watershed: A Choice Experiment Approach. Ecosyst. Serv. 2017, 23, 228-237. [CrossRef]

45. Torres, C.; Hanley, N. Communicating Research on the Economic Valuation of Coastal and Marine Ecosystem Services. Mar. Policy 2017, 75, 99-107. [CrossRef]

46. Turpie, J.K. The Existence Value of Biodiversity in South Africa: How Interest, Experience, Knowledge, Income and Perceived Level of Threat Influence Local Willingness to Pay. Ecol. Econ. 2003, 46, 199-216. [CrossRef] 